Molecules 2002, 7, 743-750

\title{
molecules
}

ISSN 1420-3049

http://www.mdpi.org

\section{Preparation of Shortened Norbelladine Analogs}

\section{Matthias Treu, Johannes Fröhlich and Ulrich Jordis*}

Institute of Applied Synthetic Chemistry, Vienna University of Technology, A-1060 Vienna, Getreidemarkt 9/163, Austria; Tel. +43 (1) 58801.15460, Fax +43(1)58801.15499,

* Author to whom correspondence should be addressed; email: ujordis@pop.tuwien.ac.at.

Received: 1 November 2001; in revised form 23 September 2002 / Accepted: 30 September 2002 /

Published: 31 October 2002

\begin{abstract}
The preparation of N-[(2-bromo-5-hydroxy-4-methoxyphenyl)methyl]-N-[(4hydroxyphenyl)methyl]formamide (5) and 2-bromo-5-hydroxy- $\alpha$-[(4-hydroxyphenyl)methyl]-4-methoxypropaneamide (10) is reported.
\end{abstract}

Keywords: O-dealkylation, norbelladine analogs.

\section{Introduction}

One of the key steps of the industrial synthesis [1] of the anti-Alzheimer drug galanthamine (Reminyl ${ }^{\circledR}$, Nivalin ${ }^{\circledR}$ ) [2] comprises a $\mathrm{K}_{3}\left[\mathrm{Fe}(\mathrm{CN})_{6}\right]$ induced phenol oxidation tandem cyclization [3]. In this reaction the 5-6-6-7 ring system is formed in one step starting from a suitable norbelladine derivative. We tried to extend this cyclization reaction towards the construction of 5-6-6-6 ring systems and prepared both N-[(2-bromo-5-hydroxy-4-methoxyphenyl)methyl]-N-[(4-hydroxyphenyl)methyl]formamide (5) and 2-bromo-5-hydroxy- $\alpha$-[(4-hydroxyphenyl)methyl]-4-methoxypropaneamide (10) as necessary intermediates. These intermediates were subjected to the conditions of the tandem cyclization [1], however the desired ring contracted galanthamine analog could not be obtained. 
<smiles>Oc1ccc(CCNCc2ccc(O)c(O)c2)cc1</smiles>

norbelladine<smiles>COc1ccc(CN(C)C)c2c1OC1(CCC(O)CC1)C2</smiles>

(-)-galanthamine

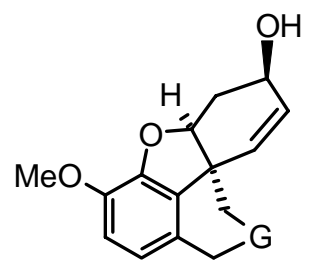

desired galanthamine analogs $\mathrm{G}=\mathrm{NMe}, \mathrm{CHCONH}_{2}$

The synthesized open chained norbelladine analogs $\mathbf{3}-\mathbf{5}$, which retain the partial structure of substituted benzylamines and thus are of potential pharmaceutical interest prompted this publication.

\section{Results and Discussion}

For the synthesis of diphenol compound (5) 1-bromo-2-(chloromethyl)-5-methoxy-4-(1methylethoxy)benzene (1) [4] was converted into an amine by reaction with potassium phthalimide with subsequent hydrazinolysis and isolated as hydrochloride salt (2) with $79 \%$ yield. Reductive amination of 4-hydroxybenzaldehyde with the free base of $\mathbf{2}$ using sodium borohydride gave rise to the secondary amine (3) with $84 \%$ yield, which was reacted with ethyl formate in presence of catalytic amount of 4-(N,N-dimethylamino)pyridine to give the amide (4) with $74 \%$ yield. Isopropyl ether cleavage was performed under mild conditions in presence of the aryl-methy-ether substructure using boron trichloride with $98 \%$ yield (see Scheme 1) to give diphenol 5 as colorless crystals.

\section{Scheme 1}

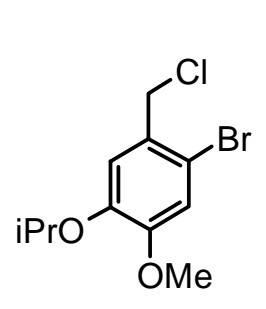

1

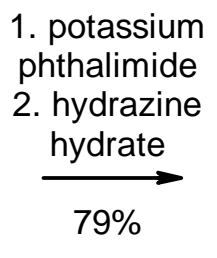

2<smiles>COc1cc(Br)c(CN)cc1OC(C)C</smiles>

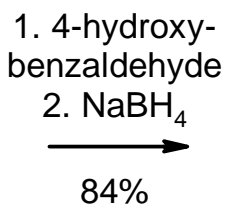<smiles>[R2]c1cc(CN([R2])Cc2ccc(O)cc2)c(Br)cc1OC</smiles>

$3 \mathrm{R} 1=\mathrm{iPr}, \mathrm{R} 2=\mathrm{H}$
$4 \mathrm{R} 1=\mathrm{iPr}, \mathrm{R} 2=\mathrm{CHO}$
$5 \mathrm{R} 1=\mathrm{H}, \mathrm{R} 2=\mathrm{CHO}$
HCOOEt $74 \%$

$\mathrm{BCl}_{3} 98 \%$

10 was prepared starting from 1-(chloromethyl)-4-(1-methylethoxy)benzene (6) [5]. Reaction with dimethyl malonate and potassium carbonate gave 7 with a yield of $78 \%$. The second alkylation step using 1-bromo-2-(chloromethyl)-5-methoxy-4-(1-methylethoxy)benzene (1) gave the ester (8) which was saponified and decarboxylated using a Kugelrohr apparatus. The obtained acid was converted into 
the amide (9) by subsequent treatment with thionyl chloride and a saturated solution of ammonia in dry formamide. Deprotection of $\mathbf{9}$, isolated as colorless crystals with $76 \%$ yield, using boron trichloride for a selective isopropyl-aryl-ether cleavage gave rise to the norbelladine analog (10) with $93 \%$ yield (see Scheme 2).

\section{Scheme 2}
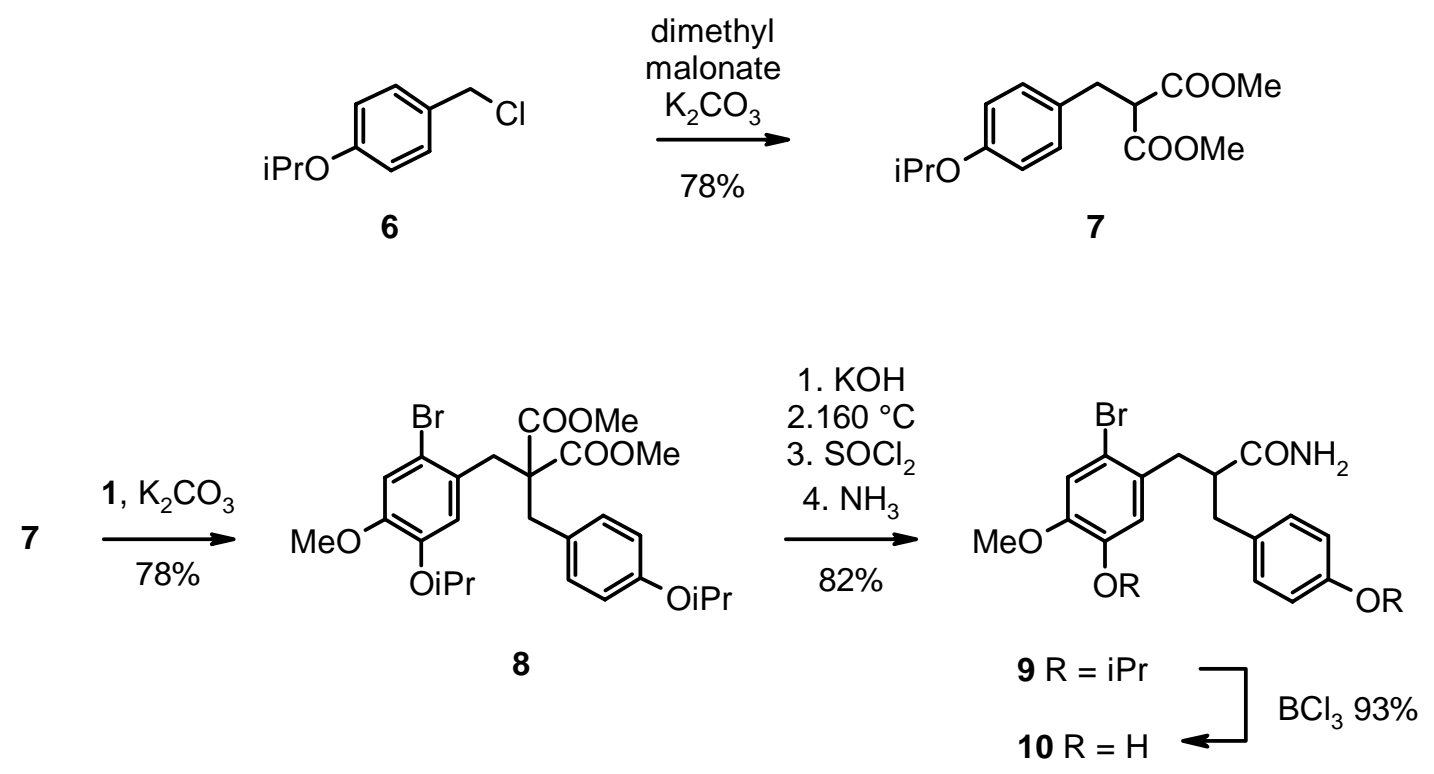

Tandem cyclization of $\mathbf{5}$ and $\mathbf{1 0}$ employing the conditions found to be optimal in the galanthamine synthesis [1] failed (see Scheme 3).

\section{Scheme 3}
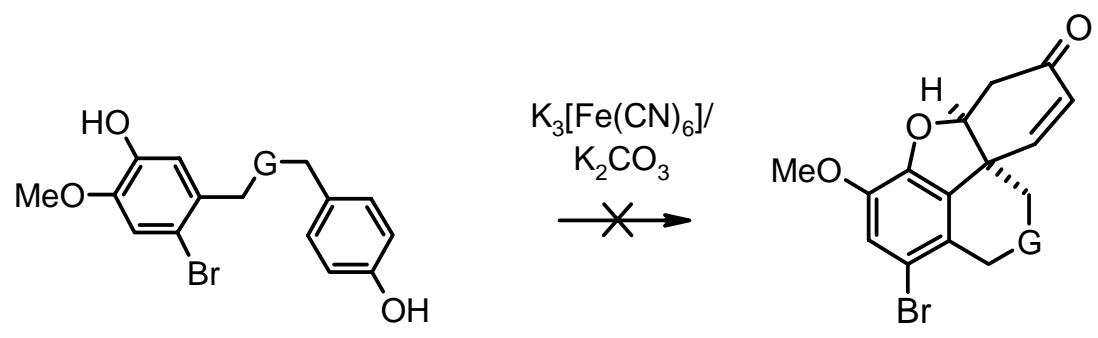

$$
\begin{aligned}
& 5 \mathrm{G}=\mathrm{NCHO} \\
& 10 \mathrm{CHCONH}_{2}
\end{aligned}
$$

\section{Conclusions}

In summary, we have developed efficient and high yielding routes towards the preparation of $\mathrm{N}-[(2-$ bromo-5-hydroxy-4-methoxyphenyl)methyl]-N-[(4-hydroxyphenyl)methyl]formamide (5) and 2bromo-5-hydroxy- $\alpha$-[(4-hydroxyphenyl)methyl]-4-methoxypropaneamide (10). Attempts to convert 
both 5 and $\mathbf{1 0}$ into their corresponding bromoformylnarwedine analogs failed. Scope and limitations of this tandem cyclization were summarized elsewhere [6].

\section{Experimental}

\section{General}

Melting points were determined on a Kofler melting point apparatus. ${ }^{1} \mathrm{H}$ - and ${ }^{13} \mathrm{C}$-NMR-spectra were recorded on a Bruker AC-200 (200 MHz) pulse Fourier-transform NMR spectrometer in $\mathrm{CDCl}_{3}$ or DMSO- $\mathrm{d}_{6}$ using tetramethylsilane as an internal standard. Thin layer chromatography (TLC) was performed on precoated plates (Merck TLC aluminum sheets silica $60 \mathrm{~F}_{254}$ ) with detection by UV light or with phosphomolybdic acid in aqueous EtOH by heating. All reactions were magnetically stirred under an argon atmosphere. MPLC (medium pressure liquid chromatography) was performed using $\mathrm{SiO}_{2}$ (Baker), a LC-8A pump (Shimadzu), a SPD-6AV UV-detector (Shimadzu) and Büchi glass columns.

2-Bromo-4-methoxy-5-(1-methylethoxy)benzenemethanamine hydrochloride (2). 1-Bromo-2-(chloromethyl)-5-methoxy-4-(1-methylethoxy)benzene (1) $(5.00 \mathrm{~g}, 17.0 \mathrm{mmol})$ and potassium phthalimide $(3.47 \mathrm{~g}, 18.7 \mathrm{mmol})$ were stirred in dry DMF $(60 \mathrm{~mL})$ for $12 \mathrm{~h}$ at $60{ }^{\circ} \mathrm{C}$. The suspension was filtered and concentrated in vacuo, and the residue was partitioned between water $(150 \mathrm{~mL})$ and $\mathrm{Et}_{2} \mathrm{O}(150$ $\mathrm{mL})$. The aqueous layer was extracted with $\mathrm{Et}_{2} \mathrm{O}(2 \times 100 \mathrm{~mL})$, the combined organic layer was washed with water $(3 \times 200 \mathrm{~mL})$ and brine $(1 \times 200 \mathrm{~mL})$, dried over $\mathrm{Na}_{2} \mathrm{SO}_{4}$, filtered and concentrated in vасио. The residue was refluxed with hydrazine hydrate $(1.28 \mathrm{~g}, 25.5 \mathrm{mmol})$ in dry EtOH $(100 \mathrm{~mL})$ for $24 \mathrm{~h}$, cooled to ambient temperature and filtered. The residue was extracted with boiling EtOH $(2 \times 25$ $\mathrm{mL}$ ), the combined extracts were added to the filtrate and concentrated in vacuo. The residue was dissolved in $\mathrm{Et}_{2} \mathrm{O}(10 \mathrm{~mL})$, cooled to $0{ }^{\circ} \mathrm{C}$ and treated with $\mathrm{HCl} / \mathrm{Et}_{2} \mathrm{O}$ (satd. at $0{ }^{\circ} \mathrm{C}$ ). The precipitated hydrochloride salt was collected by filtration and triturated with $\operatorname{dry~}_{2} \mathrm{Et}_{2} \mathrm{O}(3 \times 50 \mathrm{~mL})$. Yield: colorless needles (4.15 g, 79\%), mp. 235-237 ${ }^{\circ} \mathrm{C}$. TLC: $\mathrm{R}_{\mathrm{f}}=0.7\left(\mathrm{CHCl}_{3}-\mathrm{MeOH}-\right.$ conc. $\left.\mathrm{NH}_{3}=89: 10: 1\right)$; Anal. Calcd for $\mathrm{C}_{11} \mathrm{H}_{16} \mathrm{BrNO}_{2} * \mathrm{HCl}$ : C, 42.54; H, 5.52; N, 4.51. Found: C, 42.24; H, 5.40; N, 4.36. ${ }^{1} \mathrm{H}-\mathrm{NMR}$ $\left(\mathrm{DMSO}_{6}\right): \delta 8.73(\mathrm{~b}, 3 \mathrm{H}), 7.41(\mathrm{~s}, 1 \mathrm{H}), 7.18(\mathrm{~s}, 1 \mathrm{H}), 4.61($ septet, $J=6.3 \mathrm{~Hz}, 1 \mathrm{H}), 4.03(\mathrm{~s}, 2 \mathrm{H})$, 3.86(s, 3H), 3.47(s, 2H), $1.22(\mathrm{~d}, J=6.3 \mathrm{~Hz}, 6 \mathrm{H}) ;{ }^{13} \mathrm{C}-\mathrm{NMR}\left(\mathrm{DMSO}_{6}\right): \delta 150.5(\mathrm{~s}), 146.4(\mathrm{~s}), 124.95$ (s), 117.05 (s), 115.85 (d), 113.55 (d), 70.8 (d), 56.1 (q), 41.7 (t), 21.9 (2 q).

4-[[[2-Bromo-4-methoxy-5-(1-methylethoxy)phenylmethyl]amino]methyl]phenol (3). 2-Bromo-4methoxy-5-(1-methylethoxy)benzenemethanamine (2.28 g. $7.30 \mathrm{mmol}$, extracted from 2 by partitioning the salt between $\mathrm{CHCl}_{3}$ and conc. $\left.\mathrm{NH}_{3}\right)$ and 4-hydroxybenzaldehyde $(0.89 \mathrm{~g}, 7.30 \mathrm{mmol})$ in dry EtOH $(60 \mathrm{~mL})$ were stirred under reflux for $6 \mathrm{~h}$. The mixture was cooled to $0{ }^{\circ} \mathrm{C}$, then sodium borohydride (1.36 g, $36.5 \mathrm{mmol}$ ) was added and stirred for $30 \mathrm{~min}$ at this temperature and $1 \mathrm{~h}$ under reflux. $2 \mathrm{~N} \mathrm{HCl}$ $(10 \mathrm{~mL})$ was added, the mixture was concentrated to a volume of $5 \mathrm{~mL}$, neutralized with satd. $\mathrm{NaHCO}_{3}$ 
and extracted with $\mathrm{CHCl}_{3}(4 \times 50 \mathrm{~mL})$. The combined organic layer was washed with satd. $\mathrm{NaHCO}_{3}(2$ x $100 \mathrm{~mL})$, water $(1 \times 100 \mathrm{~mL})$ and brine $(1 \times 100 \mathrm{~mL})$, dried over $\mathrm{Na}_{2} \mathrm{SO}_{4}$, filtered and concentrated in vacuo. The residue was purified by MPLC $\left(100 \mathrm{~g} \mathrm{SiO}_{2}, \mathrm{CHCl}_{3}: \mathrm{MeOH}:\right.$ conc. $\left.\mathrm{NH}_{3}=89: 10: 1\right)$. Yield: colorless crystals $(2.34 \mathrm{~g}, 84 \%)$. An analytical sample was converted into the hydrochloride salt by treatment with $\mathrm{HCl} / \mathrm{Et}_{2} \mathrm{O}$ to give colorless crystals (mp. $\left.211-21{ }^{\circ} \mathrm{C}\right)$. TLC: $\mathrm{R}_{\mathrm{f}}=0.55\left(\mathrm{CHCl}_{3}-\right.$ $\mathrm{MeOH}$ - conc. $\left.\mathrm{NH}_{3}=89: 10: 1\right)$; Anal. Calcd for $\mathrm{C}_{18} \mathrm{H}_{22} \mathrm{BrNO}_{3} * \mathrm{HCl}$ : C, 51.88; H, 5.56; N, 3.36. Found: C, 51.93; H, 5.56; N, 3.31. ${ }^{1} \mathrm{H}-\mathrm{NMR}\left(\mathrm{DMSO}_{\mathrm{d}}\right)$ ) $\delta 9.82$ (b, 3H), 7.54 (s, 1H), 7.39 (d, J=8.9 Hz, 2H), $7.17(\mathrm{~s}, 1 \mathrm{H}), 6.82(\mathrm{~d}, J=8.9 \mathrm{~Hz}, 2 \mathrm{H}), 4.61$ (septet, $J=6,7 \mathrm{~Hz}, 1 \mathrm{H}), 4.10(\mathrm{~s}, 2 \mathrm{H}), 4.06$ (s, 2H), 3.80 (s, $3 \mathrm{H}), 1.26(\mathrm{~d}, J=6,7 \mathrm{~Hz}, 6 \mathrm{H}) ;{ }^{13} \mathrm{C}-\mathrm{NMR}\left(\mathrm{DMSO}_{6}\right): \delta 158.1(\mathrm{~s}), 150.8(\mathrm{~s}), 146.3(\mathrm{~s}), 131.8(\mathrm{~d}), 123.1$ (s), 121.5 (s), 117.7 (s), 115.8 (d), 115.4 (d), 114.4 (d), 70.8 (d), 56.0 (q), 49.4 (t), 48.3 (t), 21.9 (q).

$N$-[[2-Bromo-4-methoxy-5-(1-methylethoxy)phenyl]methyl]-N-[(4-hydroxyphenyl)-methyl]formamide (4). Compound 3 (1.50 g, $3.94 \mathrm{mmol})$, 4-(dimethylamino)pyridine (50 mg), ethyl formate $(1.4 \mathrm{~mL})$, formic acid $(0.4 \mathrm{~mL})$ and DMF $(1.5 \mathrm{~mL})$ were refluxed in dry dioxane for $6 \mathrm{~h}$. The mixture was concentrated in vacuo, and the residue was partitioned between water $(50 \mathrm{~mL})$ and EtOAc $(50 \mathrm{~mL})$. The aqueous layer was extracted with EtOAc $(3 \times 20 \mathrm{~mL})$, the combined organic layer was washed with $2 \mathrm{~N} \mathrm{HCl}(3 \times 50 \mathrm{~mL})$, water $(1 \times 50 \mathrm{~mL})$, satd. $\mathrm{NaHCO}_{3}(2 \times 50 \mathrm{~mL})$ and brine $(1 \times 100 \mathrm{~mL})$, dried over $\mathrm{Na}_{2} \mathrm{SO}_{4}$, filtered and concentrated in vacuo. The residue was triturated with tert.butylmethylether $(5 \mathrm{~mL})$. Yield: colorless crystals $(1.19 \mathrm{~g}, 74 \%)$, mp. $125-128{ }^{\circ} \mathrm{C}$. $\mathrm{TLC}: \mathrm{R}_{\mathrm{f}}=0.5$ $\left(\mathrm{CHCl}_{3}-\mathrm{MeOH}\right.$ - conc. $\left.\mathrm{NH}_{3}=89: 10: 1\right)$; Anal. Calcd for $\mathrm{C}_{19} \mathrm{H}_{22} \mathrm{BrNO}_{4}: \mathrm{C}, 55.89 ; \mathrm{H}, 5.43 ; \mathrm{N}, 3.43$. Found: C, 55.91; H, 5.43; N, 3.44. ${ }^{1} \mathrm{H}-\mathrm{NMR}\left(\mathrm{DMSO}_{6}\right): \delta 9.46$ and $9.38(\mathrm{~s}, 1 \mathrm{H}), 8.46$ and $8.40(\mathrm{~s}$, $1 \mathrm{H}), 7.12$ and $7.10(\mathrm{~s}, 1 \mathrm{H}), 7.03$ and $6.99(\mathrm{~d}, J=13.3 \mathrm{~Hz}, 2 \mathrm{H}), 6.78(\mathrm{~s}, 1 \mathrm{H}), 6.73$ and $6.99(\mathrm{~d}, J=13.3$ $\mathrm{Hz}, 2 \mathrm{H}), 4.55-4.12(\mathrm{~m}, 5 \mathrm{H}), 3.76(\mathrm{~s}, 3 \mathrm{H}), 1.32-1.12(\mathrm{~m}, 6 \mathrm{H}) ;{ }^{13} \mathrm{C}-\mathrm{NMR}\left(\mathrm{DMSO}_{\mathrm{d}}\right): \delta 163.5$ and $163.3(\mathrm{~d}), 157.0$ and 156.6 (s), 150.4 and 150.0 (s), 146.3 (s), 129.1 (s), 127.0 and 126.7 (d), 126.9 and $126.6(\mathrm{~s}), 117.2$ and 116.4 (s), 116.2 and 116.1 (d), 115.4 and $115.2(\mathrm{~d}), 113.7$ and $113(\mathrm{~d}), 70.9$ (d), $55.9(\mathrm{q}), 49.7(\mathrm{t}), 44.4$ and $43.9(\mathrm{t}), 21.8$ and $21.7(\mathrm{q})$.

$N$-[(2-Bromo-5-hydroxy-4-methoxyphenyl)methyl]-N-[(4-hydroxyphenyl)methyl]formamide (5). To 4 $(1.0 \mathrm{~g}, 2.45 \mathrm{mmol})$ in dry $\mathrm{CH}_{2} \mathrm{Cl}_{2}(5 \mathrm{~mL}) \mathrm{BCl}_{3}\left(10 \mathrm{~mL}, 10 \mathrm{mmol}, 1 \mathrm{M}\right.$ in $\left.\mathrm{CH}_{2} \mathrm{Cl}_{2}\right)$ was added at $-78^{\circ} \mathrm{C}$ and stirred for $4 \mathrm{~h}$ at ambient temperature. Water $(20 \mathrm{~mL})$ was added dropwise, and the mixture was concentrated in vacuo to a volume of $15 \mathrm{~mL}$. The precipitate was collected by filtration and triturated with water $(6 \times 20 \mathrm{~mL})$ and $\mathrm{iPr}_{2} \mathrm{O}(2 \times 10 \mathrm{~mL})$. Yield: colorless crystals (879 mg, 98\%), mp. 94 - 96 ${ }^{\circ} \mathrm{C}$. TLC: $\mathrm{R}_{\mathrm{f}}=0.2\left(\mathrm{CHCl}_{3}-\mathrm{MeOH}\right.$ - conc. $\left.\mathrm{NH}_{3}=89: 10: 1\right)$; Anal. Calcd for $\mathrm{C}_{16} \mathrm{H}_{16} \mathrm{BrNO}_{4}: \mathrm{C}, 52.84 ; \mathrm{H}$, 4.40; N, 3.82. Found: C, 52.65; H, 4.61; N, 3.67. ${ }^{1} \mathrm{H}-\mathrm{NMR}\left(\mathrm{DMSO}_{\mathrm{d}}\right): \delta 9.50(\mathrm{~b}, 1 \mathrm{H}), 9.40(\mathrm{~b}, 1 \mathrm{H})$, 8.50 and $8.40(\mathrm{~s}, 1 \mathrm{H}), 7.31-6.81(\mathrm{~m}, 3 \mathrm{H}), 6.81-6.55(\mathrm{~m}, 3 \mathrm{H}), 4.51-4.11(\mathrm{~m}, 4 \mathrm{H}), 3.79(\mathrm{~s}, 3 \mathrm{H})$; ${ }^{13}$ C-NMR (DMSO-d 6 ): $\delta 163.5$ and $163.3(\mathrm{~d}), 157.1$ and 156.7 (s), 148.3 and 147.9 (s), 146.5 (s)129.3 and 129.2 (s), 127.2 and 127.1(d), 126.6 and 126.5 (s), 116.7 and 116.3 (s), 116.0 and 115.8 (d), 115.5 and $115.4(\mathrm{~d}), 111.1$ and $110.6(\mathrm{~d}), 56.1(\mathrm{q}), 49.5$ and $49.2(\mathrm{t}), 43.7$ and $43.6(\mathrm{t})$. 
2-[4-(1-Methylethoxy)phenylmethyl]propandioic acid dimethylester (7). 1-(Chloromethyl)-4-(1methylethoxy)benzene (6) $(20.5 \mathrm{~g}, 111 \mathrm{mmol})$, dimethyl malonate $(102.5 \mathrm{~g}, 776 \mathrm{mmol})$ and potassium carbonate (46.5 g, $332 \mathrm{mmol}$, anhydrous, freshly ground) in dry DMF $(250 \mathrm{~mL})$ were stirred for $24 \mathrm{~h}$ at $70{ }^{\circ} \mathrm{C}$. The suspension was filtered and concentrated, and the residue was partitioned between water $(250 \mathrm{~mL})$ and $\mathrm{Et}_{2} \mathrm{O}(250 \mathrm{~mL})$. The aqueous layer was extracted with $\mathrm{Et}_{2} \mathrm{O}(2 \times 50 \mathrm{~mL})$, the combined organic layer was washed with water $(3 \times 200 \mathrm{~mL})$ and brine $(1 \times 150 \mathrm{~mL})$, dried over $\mathrm{Na}_{2} \mathrm{SO}_{4}$, filtered and concentrated in vacuo. The excess of dimethylmalonate was removed by distillation $\left(160{ }^{\circ} \mathrm{C} / 15\right.$ mbar), and the crude product was purified by kugelrohr distillation $\left(130{ }^{\circ} \mathrm{C} / 0.001 \mathrm{mbar}\right)$. Yield: colorless oil (23.6 g, 78\%). TLC: $\mathrm{R}_{\mathrm{f}}=0.8$ (petroleum ether - EtOAc $=9: 1$ ); Anal. Calcd for $\mathrm{C}_{15} \mathrm{H}_{20} \mathrm{O}_{5}$ : C, 64.27; H, 7.19. Found: C, 64.28; H, 7.07. ${ }^{1} \mathrm{H}-\mathrm{NMR}\left(\mathrm{CDCl}_{3}\right): \delta 7.07$ (d, $\left.J=7.6 \mathrm{~Hz}, 2 \mathrm{H}\right), 6.76(\mathrm{~d}, J=$ $7.6 \mathrm{~Hz}, 2 \mathrm{H}), 4.48$ (septet, $J=6.0 \mathrm{~Hz}, 1 \mathrm{H}), 3.67(\mathrm{~s}, 6 \mathrm{H}), 3.61(\mathrm{t}, J=8.0 \mathrm{~Hz}, 1 \mathrm{H}), 3.12(\mathrm{~d}, J=8.0 \mathrm{~Hz}$, 2H), $1.29(\mathrm{~d}, J=6.0 \mathrm{~Hz}, 6 \mathrm{H}) ;{ }^{13} \mathrm{C}-\mathrm{NMR}\left(\mathrm{CDCl}_{3}\right): \delta 169.1(\mathrm{~s}), 156.6(\mathrm{~s}), 129.6(\mathrm{~d}), 129.4(\mathrm{~s}), 115.8(\mathrm{~d})$, $69.6(\mathrm{~d}), 53.7(\mathrm{~d}), 52.3(\mathrm{q}), 33.8(\mathrm{t}), 21.9(\mathrm{q})$.

2-[[2-Bromo-4-methoxy-5-(1-methylethoxy)phenyl]methyl]-2-[[4-(1-methylethoxy)phenyl]methyl]-

propanedioic acid dimethylester (8). Compound 7 (2.50 g, $8.92 \mathrm{mmol})$, 1-bromo-2-chloromethyl-5methoxy-4-(1-methylethoxy)benzene (1) $(2.62 \mathrm{~g}, 8.92 \mathrm{mmol})$ and potassium carbonate $(3.71 \mathrm{~g}, 26.8$ mmol, anhydrous, freshly ground) in dry acetonitrile $(100 \mathrm{~mL})$ were stirred for $24 \mathrm{~h}$ at $60{ }^{\circ} \mathrm{C}$. The suspension was filtered and concentrated, and the residue was partitioned between water $(100 \mathrm{~mL})$ and $\mathrm{Et}_{2} \mathrm{O}(100 \mathrm{~mL})$. The aqueous layer was extracted with $\mathrm{Et}_{2} \mathrm{O}(1 \times 50 \mathrm{~mL})$, the combined organic layer was washed with water $(3 \times 100 \mathrm{~mL})$ and brine $(1 \times 100 \mathrm{~mL})$, dried over $\mathrm{Na}_{2} \mathrm{SO}_{4}$, filtered and concentrated in vacuo. The crude product was purified by kugelrohr distillation $\left(180{ }^{\circ} \mathrm{C} / 0.01 \mathrm{mbar}\right)$. Yield: colorless oil (3.93 g, 82\%). TLC: $\mathrm{R}_{\mathrm{f}}=0.5$ (petroleum ether - EtOAc $\left.=9: 1\right) ;{ }^{1} \mathrm{H}-\mathrm{NMR}\left(\mathrm{CDCl}_{3}\right): \delta$ $7.02(\mathrm{~d}, J=8.1 \mathrm{~Hz}, 2 \mathrm{H}), 7.00(\mathrm{~s}, 1 \mathrm{H}), 6.89(\mathrm{~s}, 1 \mathrm{H}), 6.78(\mathrm{~d}, J=8.1 \mathrm{~Hz}, 2 \mathrm{H}), 4.58-4.31(\mathrm{~m}, 2 \mathrm{H}), 3.78$ $(\mathrm{s}, 3 \mathrm{H}), 3.59(\mathrm{~s}, 6 \mathrm{H}), 3.37(\mathrm{~s}, 2 \mathrm{H}), 3.26(\mathrm{~s}, 2 \mathrm{H}), 1.37-1.26(\mathrm{~m}, 12 \mathrm{H}) ;{ }^{13} \mathrm{C}-\mathrm{NMR}\left(\mathrm{CDCl}_{3}\right): \delta 171.2(\mathrm{~s})$, 156.8 (s), 149.5 (s), 146.1 (s), 130.9 (d), 128.1 (s), 127.8 (s), 118.0 (s), 116.1 (s), 115.8 (d), 115.5 (d), $71.3(\mathrm{~d}), 69.7(\mathrm{~d}), 60.2(\mathrm{~s}), 56.0(\mathrm{q}), 52.2(\mathrm{q}), 39.9(\mathrm{t}), 38.6(\mathrm{t}), 22.0(\mathrm{q}), 21.9(\mathrm{q})$.

\section{2-Bromo-4-methoxy-5-(1-methylethoxy)- $\alpha$-[[4-(1-methylethoxy)phenyl]methyl]-benzenepropanamide}

(9). Compound $8(3.93 \mathrm{~g}, 7.31 \mathrm{mmol})$ and $\mathrm{KOH}(1.50 \mathrm{~g}, 26.8 \mathrm{mmol})$ were stirred in $\mathrm{EtOH}(50$ $\mathrm{mL}) /$ water $(5 \mathrm{~mL})$ under reflux for $12 \mathrm{~h}$. The solution was concentrated to $5 \mathrm{~mL}$ in vacuo, a $\mathrm{pH}<1$ was adjusted by dropwise addition conc. $\mathrm{HCl}$, and the mixture was partitioned between water $(100 \mathrm{~mL})$ and $\mathrm{Et}_{2} \mathrm{O}(100 \mathrm{~mL})$. The aqueous layer was extracted with $\mathrm{Et}_{2} \mathrm{O}(2 \times 50 \mathrm{~mL})$, the combined organic layer was washed with water $(3 \times 100 \mathrm{~mL})$ and brine $(1 \times 100 \mathrm{~mL})$, dried over $\mathrm{Na}_{2} \mathrm{SO}_{4}$, filtered and concentrated in vacuo. The residue was decarboxylated using a kugelrohr apparatus $\left(160^{\circ} \mathrm{C}, 30 \mathrm{~min}\right)$, and the formed carboxylic acid was purified by subsequent distillation $\left(165{ }^{\circ} \mathrm{C} / 0.01 \mathrm{mbar}\right)$. The distillate was dissolved in thionyl chloride $(10 \mathrm{~mL})$, then DMF $(100 \mu \mathrm{L})$ was added and stirred for $6 \mathrm{~h}$ 
at ambient temperature. The mixture was concentrated in vacuo, dissolved in dry formamide, cooled to $0{ }^{\circ} \mathrm{C}$ and treated with a solution of $\mathrm{NH}_{3}$ in formamide $\left(20 \mathrm{~mL}\right.$, saturated at $\left.0{ }^{\circ} \mathrm{C}\right)$. The mixture was stirred for $1 \mathrm{~h}$ and poured into water $(500 \mathrm{~mL})$. The precipitate was collected by filtration and triturated with water $(5 \times 100 \mathrm{~mL})$. Yield: colorless crystals $(2.58 \mathrm{~g}, 76 \%)$, mp. $129-131{ }^{\circ} \mathrm{C}$. TLC: $\mathrm{R}_{\mathrm{f}}=0.7$ $\left(\mathrm{CH}_{2} \mathrm{Cl}_{2}-\mathrm{MeOH}=9: 1\right)$; Anal. Calcd for $\mathrm{C}_{23} \mathrm{H}_{30} \mathrm{BrNO}_{4}: \mathrm{C}, 59.49 ; \mathrm{H}, 6.51 ; \mathrm{N}, 3.02$. Found: $\mathrm{C}, 59.22$; H, 6.24; N, 2.90. ${ }^{1} \mathrm{H}-\mathrm{NMR}\left(\mathrm{DMSO}_{-} \mathrm{d}_{6}\right): \delta 7.22(\mathrm{~b}, 1 \mathrm{H}), 7.10(\mathrm{~d}, J=8.1 \mathrm{~Hz}, 2 \mathrm{H}), 7.07$ (s, 1H), 6.88 (s, 1H), $6.80(\mathrm{~d}, J=8.1 \mathrm{~Hz}, 2 \mathrm{H}), 6.71(\mathrm{~b}, 1 \mathrm{H}), 4.76-4.46(\mathrm{~m}, 2 \mathrm{H}), 3.39(\mathrm{~s}, 3 \mathrm{H}), 2.98-2.34(\mathrm{~m}, 5 \mathrm{H}), 1.38$ - $1.07(\mathrm{~m}, 12 \mathrm{H}) ;{ }^{13} \mathrm{C}-\mathrm{NMR}\left(\mathrm{DMSO}_{\mathrm{d}}\right): \delta 175.5(\mathrm{~s}), 155.8(\mathrm{~s}), 149.1(\mathrm{~s}), 145.8(\mathrm{~s}), 131.4(\mathrm{~s}), 131.0(\mathrm{~s})$, 129.9 (d), 118.1 (s), 115.9 (d), 115.4 d), 114.1 (d), 70.7 (d), 69.0 (d), 55.8 (q), 48.0 (d), 37.6 (t), 37.0 $(\mathrm{t}), 22.0(\mathrm{q}), 21.9(\mathrm{q}), 21.8(\mathrm{q})$.

2-Bromo-5-hydroxy- $\alpha$-[(4-hydroxyphenyl)methyl]-4-methoxypropanamide (10). To $92.00 \mathrm{~g}, 4.31$ mmol $)$ in dry $\mathrm{CH}_{2} \mathrm{Cl}_{2}(30 \mathrm{~mL}) \mathrm{BCl}_{3}\left(10 \mathrm{~mL}, 16 \mathrm{mmol}, 1.6 \mathrm{M}^{\text {in }} \mathrm{CH}_{2} \mathrm{Cl}_{2}\right)$ was added at $-78{ }^{\circ} \mathrm{C}$ and stirred for $1 \mathrm{~h}$ at this temperature and for additional $2 \mathrm{~h}$ at ambient temperature. Water $(100 \mathrm{~mL})$ was added dropwise, and the mixture was concentrated in vacuo to a volume of $80 \mathrm{~mL}$. The precipitate was collected by filtration and triturated with water $(6 \times 50 \mathrm{~mL})$ and ${ }^{\mathrm{iPr}} 2 \mathrm{O}(2 \times 10 \mathrm{~mL})$. Yield: colorless crystals $(1.52 \mathrm{~g}, 93 \%)$, mp. $174-176{ }^{\circ} \mathrm{C}$. TLC: $\mathrm{R}_{\mathrm{f}}=0.4\left(\mathrm{CH}_{2} \mathrm{Cl}_{2}-\mathrm{MeOH}=9: 1\right)$; Anal. Calcd for $\mathrm{C}_{17} \mathrm{H}_{18} \mathrm{BrNO}_{4}$ : C, 53.70; H, 4.77; N, 3.68. Found: C, 53.48; H, 4.66; N, 3.50. ${ }^{1} \mathrm{H}-\mathrm{NMR}$ (DMSO-d ${ }_{6}$ ): $\delta$ $9.21(\mathrm{~b}, 2 \mathrm{H}), 7.21(\mathrm{~b}, 1 \mathrm{H}), 7.13-6.89(\mathrm{~m}, 3 \mathrm{H}), 6.87-6.51(\mathrm{~m}, 4 \mathrm{H}), 3.72(\mathrm{~s}, 3 \mathrm{H}), 2.93-2.30(\mathrm{~m}, 5 \mathrm{H})$;

${ }^{13}$ C-NMR (DMSO-d $\left.{ }_{6}\right): \delta 175.9(\mathrm{~s}), 155.6(\mathrm{~s}), 147.1(\mathrm{~s}), 145.8(\mathrm{~s}), 131.4(\mathrm{~s}), 130.0(\mathrm{~d}), 129.9(\mathrm{~s}), 118.0$ (s), 115.9 (d), 115.1 (d), 112.0 (d), 56.0 (q), $48.2(\mathrm{~d}), 37.7(\mathrm{t}), 37.1(\mathrm{t})$.

\section{References}

1. Kueenburg, B.; Czollner, L.; Froehlich, J.; Jordis, U. Development of a pilot scale process for the anti-Alzheimer drug (-)-galanthamine using large-scale phenolic oxidative coupling and crystallisation-induced chiral conversion. Org. Process Res. Dev. 1999, 3, 425 - 431.

2. Han, S. Y.; Sweeney, J. E.; Bachman, E. S.; Schweiger, E. J.; Forloni, G.; Coyle, J. T.; Davis, B. M.; Joullie, M. M. Chemical and pharmacological characterization of galanthamine, an acetylcholinesterase inhibitor, and its derivatives. A potential application in Alzheimer's disease? Eur. J. Med. Chem. 1992, 27, 673 - 687.

3. Barton, D. H. R.; Kirby, G. W. Phenol oxidation and biosynthesis. V. Synthesis of galanthamine. J. Chem. Soc. 1962, 806 - 817.

4. Treu, M.; Jordis, U.; Mereiter, K. 12H-[2]-Benzothiepino[6,5a,5-bc]benzofuran: Synthesis of a Sulfur-Analog of Galanthamine. Heterocycles, 2001, 55, 1727 - 1735.

5. Kuchar, M.; Brunova, B.; Rejholec, V.; Grimova, J.; Nemecek, O. Substituted benzyloxyarylacetic acids: synthesis and quantitative relations between structure and antiinflammatory activity. Collect. Czech. Chem. Commun. 1977, 42, 1723 - 1735. 
6. Treu, M. and Jordis, U. Carbocyclic galanthamine analogs - construction of the novel $6 \mathrm{H}-$ benzo[a]cyclohepta[hi]benzofuran ring system. Mendeleev Commun. 2002, 2, 52 - 53.

Samples Availability: Available from the authors.

(C) 2002 by MDPI (http://www.mdpi.org). Reproduction is permitted for noncommercial purposes. 